\title{
PERAN KEPUASAN PELANGGAN DALAM MEMEDIASI PENGARUH KUALITAS PRODUK TERHADAP LOYALITAS PELANGGAN KFC DI KOTA DENPASAR
}

\author{
Ni Made Desy Shinta Sari ${ }^{1}$ \\ I Made Jatra ${ }^{2}$
}
${ }^{1,2}$ Fakultas Ekonomi dan Bisnis Universitas Udayana (Unud), Bali, Indonesia email: desyshintaa14@gmail.com

\begin{abstract}
ABSTRAK
Tujuan penelitian ini adalah untuk mengetahui pengaruh peran kepuasan pelanggan dalam memediasi pengaruh kualitas produk terhadap loyalitas pelanggan. Penelitian ini berlokasi di Kota Denpasar melibatkan 100 responden yang pernah mengkonsumsi KFC lebih dari sekali dengan metode purposive sampling, dikumpulkan melalui kuesioner menggunakan teknik analisis statistik deskriptif dan analisis jalur serta uji sobel.Berdasarkan hasil analisis ditemukan bahwa kualitas produk berpengaruh positif signifikan terhadap kepuasan pelanggan. Semakin tinggi kualitas yang diberikan, maka semakin tinggi pula tingkat kepuasan yang dirasakan. Kualitas produk berpengaruh positif signifikan terhadap loyalitas pelanggan. Semakin tinggi kualitas produk, maka semakin tinggi pula tingkat loyalitas pelanggan terhadap suatu produk. Kepuasan pelanggan berpengaruh positif signifikan terhadap loyalitas pelanggan. Semakin tinggi tingkat kepuasan pelanggan, maka semakin tinggi pula tingkat loyalitas pelanggan terhadap produk yang diberikan. Kepuasan pelanggan mampu memediasi pengaruh kualitas produk terhadap loyalitas pelanggan. Peran mediasi yang dimiliki kepuasan pelanggan secara tidak langsung mempengaruhi kualitas produk terhadap loyalitas pelanggan.
\end{abstract}

Kata kunci: kualitas produk, kepuasan pelanggan, loyalitas pelanggan

\begin{abstract}
The purpose of this study was to determine the effect of the role of customer satisfaction in mediating the effect of product quality on customer loyalty. This study located in Denpasar City involved 100 respondents who had consumed KFC more than once with the purposive sampling method, collected through a questionnaire using descriptive statistical analysis techniques and path analysis and sobel test. Based on the results of the analysis it was found that product quality had a significant positive effect on customer satisfaction. The higher the quality provided, the higher the level of satisfaction felt. Product quality has a significant positive effect on customer loyalty. The higher the quality of the product, the higher the level of customer loyalty for a product. Customer satisfaction has a significant positive effect on customer loyalty. The higher the level of customer satisfaction, the higher the level of customer loyalty to the product provided. Customer satisfaction is able to mediate the influence of product quality on customer loyalty. The role of mediation owned by customer satisfaction indirectly affects product quality towards customer loyalty.

Keywords: product quality, customer satisfaction, customer loyalty
\end{abstract}




\section{PENDAHULUAN}

Perkembangan zaman dan teknologi yang sangat pesat berdampak pada perubahan pola pikir masyarakat yang juga semakin berkembang.Pola pikir masyarakat yang semakin berkembangmenyebabkan berubahnya gaya hidup menjadi semakin kompleks. Fenomena tersebut pada dasarnya disebabkan oleh mobilitas masyarakat perkotaan yang semakin cepat dan menyukai segala sesuatu yang praktis, didukung dengan padatnya aktivitas keluarga diluar rumah sehingga tidak ada waktu untuk menyiapkan makanan (Mufidah, 2012). Pergeseran pola konsumsi masyarakat Indonesia pada makanan cepat saji tersebut menyebabkan perkembangan restoran cepat saji (fast food) dari tahun ketahun semakin meningkat. Hal ini diperkuat oleh data terkait jumlah/unit gerai restoran cepat saji di Indonesia yang terus meningkat seperti yang ditunjukkan dalam Tabel 1. berikut:

\section{Tabel 1.}

Jumlah Unit/Gerai Restoran Cepat Saji di Indonesia 2012-2016

\begin{tabular}{lrrrrr}
\hline \multicolumn{1}{c}{ Kategori } & $\mathbf{2 0 1 2}$ & $\mathbf{2 0 1 3}$ & $\mathbf{2 0 1 4}$ & $\mathbf{2 0 1 5}$ & $\mathbf{2 0 1 6}$ \\
\hline Waralaba & 3719 & 4074 & 4423 & 4775 & 5138 \\
Non Waralaba & 1508 & 1534 & 1555 & 1574 & 1589 \\
Total Restoran Cepat Saji & 5227 & 5608 & 5978 & 6349 & 6727 \\
\hline
\end{tabular}

Sumber:Euromonitor International, 2018

Tabel 1. menunjukkan bahwa jumlah/unit gerai restoran cepat saji di Indonesia dari tahun 2012 hingga 2016 terus mengalami peningkatan.Peningkatan jumlah restoran cepat saji (fast food) tersebut menimbulkan persaingan yang semakin ketat, agar dapat memenangkan persaingan tersebut perusahaan dituntut memiliki keunggulan tersendiri untuk memikat konsumen sehingga dapat mempertahankan pangsa pasar yang sudah ada.

Loyalitas pelanggan (customer loyalty) merupakan respon yang berkaitan erat dengan ikrar untuk memegang teguh komitmen yang mendasari keberlanjutan relasi, dan biasanya tercermin dalam pembelian ulang yang konsisten (Tjiptono \& Gregorius, 2015). Salah satu faktor kunci yang menjadi perhatian perusahaan adalah loyalitas konsumen (Mise et al., 2013). Loyalitas tidak tumbuh begitu saja, tetapi diperlukan strategi dalam hal pengelolaan konsumen guna memperolehnya. Perusahaan harus mampu mengenal apa yang menjadi kebutuhan dan harapan konsumen saat ini maupun yang akan datang (Pradipta, 2012).

Loyalitas konsumen memang sangat penting untuk kelangsungan hidup perusahaan, maka dari itu banyak perusahaan menggunakan strategi pemasaran untuk meningkatkan pangsa pasar mereka.Komitmen yang kuat menunjukan "sikap" untuk sebuah merek bahwa benar loyalitas ada (Pishgar et al., 2017). Mempertahankan loyalitas pelanggan adalah salah satu cara utama untuk mendapatkan pelanggan baru. Loyalitas pelanggan tercipta melalui kepuasan pelanggan atas kualitas produk yang dikonsumsi, jika pelanggan merasa harapannya terpenuhi maka akan mengarah kepada loyalitas. Kualitas suatu produk menjelaskan kemampuan suatu produk atau merek, apakah sudah sesuai dengan manfaat dan fungsinya. Bilamana suatu produk atau merek didapati kurang sesuai dengan kualitas yang diinginkan, maka pelanggan akan merasa 
kecewa dan yang paling merugikan lagi akan berpaling ke produk atau merek lain yang sejenis. Oleh sebab itu, suatu produk yang berkualitas harus dapat meningkatkan kepuasan pelanggan (Amri, 2013).

Menurut Tjiptono \& Gregorius (2015) kualitas mencerminkan semua dimensi penawaran produk yang menghasilkan manfaat (benefits) bagi pelanggan, sedangkan menurut Wahjono(2010)segala hal yang dapat memenuhi kebutuhan dan keinginan masyarakat merupakan fungsi dari suatu produk. Meningkatkan kualitas suatu produk merupakan salah satu strategi perusahaan dalam menarik perhatian para pelanggan. Konsumen akan menggunakan penilaian mereka dalam menentukan dan membuat keputusan, terutama saat membeli produk yang berkualitas (Ackaradejruangsri, 2013). Hal ini berarti konsumen akan lebih memilih produk yang kualitasnya lebih baik dibanding yang kualitasnya lebih rendah.

Kualitas produk dapat mempengaruhi loyalitas pelanggan. Penelitian sebelumnya yang dilakukan oleh Suwarni \& Mayasari (2011) dan Afshar et al. (2011) menyatakan bahwa terdapat pengaruh yang signifikan antara kualitas produk terhadap loyalitas konsumen. Begitu pula dengan penelitian Halim et al. (2014) yang menyatakan bahwa terdapat pengaruh positif dan signifikan antara kualitas produk dengan loyalitas pelanggan.Namun penelitian yang berbeda ditemukan Pongoh (2013) yang mengatakan bahwa kualitas produk berpengaruh positif tidak signifikan terhadap loyalitas pelanggan.Penelitian lainnya juga dilakukan oleh Sembiring dkk. (2014) menyatakan bahwa kualitas produk terbukti memiliki pengaruh yang tidak signifikan terhadap loyalitas pelanggan.

Kualitas produk selain berpengaruh kepada loyalitas pelanggan, juga dapat berpengaruh kepada kepuasan pelanggan.Hasil penelitian sebelumnya yang dilakukan oleh Gaol \& Hidayat (2016) menemukan hasil bahwa kualitas produk berpengaruh positif dan signifikan terhadap tingkat kepuasan konsumen. Penelitian serupa yang dilakukan oleh Windawati (2008) dan Asgharian et al. (2012) mengatakan bahwa kualitas produk berpengaruh positif dan signifikan terhadap kepuasan pelanggan, sedangkan menurut penelitian Haryanto (2013)kualitas produk memiliki pengaruh signifikan terhadap kepuasan pelanggan. Sejalan dengan penelitian dari Christian (2013)yang menyatakan adanya pengaruh yang signifikan antara kualitas produk terhadap kepuasan pelanggan.Semakin tinggi tingkat kualitas produk yang diberikan, maka semakin tinggi pula tingkat kepuasan konsumen yang dihasilkan. Kualitas produk sangat menentukan keinginan konsumen, sehingga dengan memberikan kualitas produk yang baik maka akan tercapai suatu kepuasan tersendiri bagi konsumen.

Menurut Kotler (2012) mendefinisikan bahwa kepuasan pelanggan merupakan perasaan puas atau kecewa seseorang yang dihasilkan dari perbandingan performa produk atau hasil dengan ekspektasi, sedangkan menurut penelitian Ruggieri \& Silvestri (2014) kepuasan adalah patokan untuk menilai sebuah kualitas produk dan layanan. Kepuasan pelanggan, secara umum mengarah pada persepsi yang rumit, terkait dengan ekspektasi klien yang ditentukan baik dengan faktor kualitas objektif dan interaksi subjektif yang menentukan pengalaman pelanggan saat membeli atau menggunakan produk atau jasa tersebut. Faktor kepuasan akan diperoleh konsumen dalam proses konsumsi 
atau penggunaan suatu produk (Farida, 2014). Terjadinya kepuasan atau ketidakpuasan pasca pembelian konsumen terhadap suatu produk mempengaruhi perilaku selanjutnya. Jika konsumen merasa puas, maka akan menunjukkan kembali produk tersebut (Kotler, 2012). Kepuasan pelanggan juga merupakan kunci untuk menciptakan loyalitas pelanggan, karena pelanggan yang puas akan cenderung loyal (Lailia et al., 2010).

Penelitian sebelumnya yang dilakukan oleh Deng et al. (2010), Akbar \& Parvez (2009) dan Thakur \& Singh (2011) menunjukkan bahwa kepuasan konsumen secara signifikan dapat mempengaruhi loyalitas konsumen. Sejalan dengan penelitian dari Damayanti \& Wahyono (2015) dan Román (2010) yang menunjukan hasil bahwa kepuasan konsumen memiliki pengaruh yang signifikan terhadap loyalitas konsumen. Di dukung juga dengan penelitian lain dari Asgharian et al. (2012) yang menyatakan bahwa kepuasan pelanggan berpengaruh positif terhadap loyalitas pelanggan. Namun hasil yang berbeda ditemukan dalam penelitian Shahin et al. (2011) dan Wiguno (2014) yang menyatakan bahwa kepuasan konsumen memiliki pengaruh yang tidak signifikan terhadap loyalitas konsumen.

Berdasarkan penelitian terdahulu oleh Amaranggana \& Rahanatha (2018) kepuasan dapat memediasi pengaruh kualitas produk terhadap loyalitas pelanggan, yang mengindikasikan bahwa kualitas produk yang disertai oleh kepuasan akan mempengaruhi loyalitas pelanggan pada suatu produk.

Salah satu restoran cepat saji yang banyak diminati oleh konsumen di Indonesia adalah KFC (Kentucky Fried Chicken). PT. Fast Food Indonesia, Tbk dengan merek dagang Kentucky Fried Chicken pertama kali berdiri pada tahun 1930 di Sanders Court, Amerika oleh Harland Sanders. KFC mulai dikenal pada Oktober 1979 dengan dibukanya restoran KFC pertama di Jalan Melawai, Jakarta Selatan.Dari awal beroprasi, KFC memiliki daya saing produk yang mampu menempatkan KFC sebagai restoran dengan hasil olahan ayam goreng yang lezat dengan produk unggulannya yaitu Original Recipe Chicken dan Hot and Crispy Chicken.

KFC berhasil mendapat Top Brand Award dalam kategori restoran cepat saji (fast food).Top Brand didasarkan atas hasil riset terhadap konsumen di beberapa kota besar di Indonesia yaitu Jakarta, Bandung, Semarang, Surabaya, Medan, Makassar, Pekanbaru, Balikpapan, Denpasar, Palembang, dan Samarinda. Top Brand Index(TBI) diukur dengan menggunakan tiga parameter yaitu top of mind awareness (produk pertama yang disebut responden ketika mendengar suatu kategori produk), last used (produk terakhir yang dikonsumsi atau digunakan oleh responden dalam satu siklus pembelian ulang), dan future intention (produk yang ingin dikonsumsi atau digunakan oleh responden di masa mendatang).

Pada Tabel 2. restoran cepat saji (fast food) yang telah berhasil masuk dalam Top Brand Index 2016, 2017, dan 2018 pada fase 2. Hasil Top Brand Index menunjukkan bahwaKFC menjadiperingkat pertamatahun 2016sampaitahun 2018padakategori restoran cepat saji (fast food). Dari data Top Brand Index terlihat bahwa KFC menguasi pangsa pasar makanan siap saji di Indonesia walaupun 3 tahun terakhir mengalami penurunan. Kota-kota besar di Indonesia menjadi tujuan pemasaran makanan cepat saji. Kota Denpasar merupakan salah satu kota dengan 
restoran cepat saji terbanyak, yang tentu saja menjadikan persaingan restoran cepat saji semakin ketat. Salah satu restoran cepat saji yang bersaing ketat di Kota Denpasar yaitu KFC dengan memiliki jumlah gerai terbanyak, berikut daftar jumlah gerai restoran cepat saji di Denpasar.

Tabel 2.

Top Brand IndexKategori Restoran Cepat Saji (Persentase)

\begin{tabular}{cccc}
\hline Merek & TBI 2016 & TBI 2017 & TBI 2018 \\
\hline KFC & 63.9 & 60.4 & 42.7 \\
MC Donald's & 18.6 & 19.0 & 24.3 \\
A\&W & 2.6 & 2.9 & 6.3 \\
CFC & 2.0 & 5.8 & - \\
Hoka-Hoka Bento & 2.5 & 3.7 & 5.8 \\
\hline Sumber: www.topbrand-award.com, 2018 & &
\end{tabular}

Tabel 3.

Jumlah Gerai Restoran Cepat Saji di Indonesia dan Denpasar 2018

\begin{tabular}{cccc}
\hline No & $\begin{array}{c}\text { Merek } \\
\text { Dagang }\end{array}$ & $\begin{array}{c}\text { Jumlah Gerai } \\
\text { Seluruh Indonesia }\end{array}$ & $\begin{array}{c}\text { Jumlah Gerai } \\
\text { Di Kota Denpasar }\end{array}$ \\
\hline 1 & KFC & 628 & 11 \\
2 & McDonald's & 180 & 7 \\
3 & A\&W & 200 & 0 \\
4 & CFC & 285 & 1 \\
5 & Hoka-Hoka Bento & 143 & 1 \\
\hline
\end{tabular}

Tabel 3. memperlihatkan bahwa di Kota Denpasar gerai KFC tercatat sebanyak 11 gerai yang tersebar di seluruh kota. Jumlah tersebut hanya sebagian dari jumlah keseluruhan gerai KFC yaitu 628 hingga bulan Juni 2018 lalu. Strategi inovasi yang dilakukan KFC telah berhasil menjadikan KFC sebagai top of mind di masyarakat. Salah satu brandyang diluncurkan PT. Fast Food Indonesia ini tentu sangat dikenali oleh masyarakat luas dari kalangan manapun dengan usia yang berbeda. Hal tersebut dibuktikan KFC dengan diraihnya banyak penghargaan bergengsi sepanjang tahun 2018, meliputi Indonesia Top Digital PR, Indonesia WOW Brand, Indonesia Most Innovative Business, Top Brand For Kids, Top Brand For Teens, Service Quality, Indonesia Digital Popular Brand, Halal dan Indonesia Content Marketing Awards.

Meski KFC mendapat banyak penghargaan tidak menutup kemungkinan pelanggan selalu puas dengan kualitas produk yang ditawarkan. Salah satu pelanggan KFC mengungkapkan keluhan terhadap produk KFC yang tidak sesuai dengan pesanan. Pelanggan tersebut lebih kecewa lagi setelah mengupas kulitnya ternyata daging ayam tersebut kering, berwarna kusam, tidak panas dan rasanyapun sudah tidak seperti daging segar lagi. Maka dari itu, perlu adanya peningkatan kualitas produk KFC yang masih kurang melalui pengolahan produk oleh koki professional dan pembuatan penyajian makanan yang berinovasi agar mengikuti selera konsumen (Prasastono \& Pradapa, 2012).

Untuk memperkuat argumentasi mengenai peran kepuasan pelanggan dalam memediasi pengaruh kualitas produk terhadap loyalitas pelanggan maka dilakukan 
pra-survey dengan mengajukan pernyataan terkait dilakukan oleh 20 responden yang telah menjadi pelanggan KFC.Hasil pra-survey tertera pada Tabel 4.

Tabel 4.

Tabel Pernyataan Pra-survey

\begin{tabular}{|c|c|c|c|c|c|c|}
\hline No & Variabel & Indikator & Pernyataan & Setuju & $\begin{array}{c}\text { Tidak } \\
\text { Setuju }\end{array}$ & Jumlah \\
\hline 1. & $\begin{array}{l}\text { Kualitas } \\
\text { Produk }\end{array}$ & Keandalan & $\begin{array}{l}\text { Saya merasa KFC } \text { selalu } \\
\text { memberikan produk dengan } \\
\text { rasa dan tampilan yang } \\
\text { menarik. }\end{array}$ & 6 & 14 & 20 \\
\hline 2. & $\begin{array}{l}\text { Kepuasan } \\
\text { Pelanggan }\end{array}$ & $\begin{array}{c}\text { Kepuasan } \\
\text { Keseluruhan }\end{array}$ & $\begin{array}{l}\text { Saya merasa puas secara } \\
\text { keseluruhan terhadap kualitas } \\
\text { KFC. }\end{array}$ & 9 & 11 & 20 \\
\hline 3. & $\begin{array}{l}\text { Loyalitas } \\
\text { Pelanggan }\end{array}$ & $\begin{array}{l}\text { Niat Membeli } \\
\text { Kembali }\end{array}$ & $\begin{array}{l}\text { Saya akan membeli kembali } \\
\text { produk KFC secara berulang- } \\
\text { ulang. }\end{array}$ & 10 & 10 & 20 \\
\hline
\end{tabular}

Sumber: Data diolah, 2019

Pada Tabel 4. hasil pra-survey diketahui bahwa pernyataan mengenai kualitas produk hanya 6 orang yang merasa setuju.Untuk kepuasan pelanggan 9 orang yang merasa setuju dengan pernyataan.Sedangkan untuk niat membeli kembali setengah dari responden merasa masih mau mengkonsumsi dan membeli kembali produk KFC. Hal ini dapat diartikan bahwa konsumen merasa kualitas produk yang diberikan oleh KFC dapat dikategorikan kurang baik sehingga konsumen merasa tidak puas dengan kualitas produk tersebut.Namun beberapa konsumen masih mau mengkonsumsi dan membeli kembali produk KFC dengan beberapa faktor yang mendorongnya.

Kualitas produk didefinisikan sebagai segala sesuatu yang memuaskan pelanggan atau sesuai dengan persyaratan atau kebutuhan. Berdasarkan penelitian Chang\&Fong (2010)dan Asgharian et al. (2012)mengatakan bahwa kualitas produk berpengaruh positif dan signifikan terhadap kepuasan pelanggan, sedangkan menurut penelitian Haryanto(2013)mengatakan bahwa kualitas produk memiliki pengaruh signifikan terhadap kepuasan pelanggan. Sejalan dengan penelitian dari Christian (2013) menyatakan adanya pengaruh yang signifikan antara kualitas produk terhadap kepuasan pelanggan.

Berdasarkan hasil empiris pada penelitian sebelumnya, hipotesis yang dapat diajukan dalam penelitian ini adalah :

$\mathrm{H}_{1}$ : Kualitas produk berpengaruh positif dan sigifikan terhadap kepuasan pelanggan.

Loyalitas adalah "komitmen yang dipegang secara mendalam untuk membeli atau mendukung kembali produk atau jasa yang disukai di masa depan meski pengaruh situasi dan usaha pemasaran berpotensi menyebabkan pelanggan beralih". Semakin baik kualitas suatu produk, maka akan semakin tinggi pula tingkat loyalitas pelanggan pada suatu produk (Sutrisni, 2010). Menurut penelitian Alfin (2013) menyatakan bahwa adanya pengaruh signifikan antara kualitas produk terhadap loyalitas pelanggan. Sejalan dengan penelitian Kurniawati dkk. 
(2014) yang mengatakan bahwa kualitas produk diketahui memiliki pengaruh signifikan terhadap loyalitas pelanggan.

Berdasarkan hasil empiris pada penelitian sebelumnya, hipotesis yang dapat diajukan dalam penelitian ini adalah :

$\mathrm{H}_{2}$ : Kualitas produk berpengaruh positif dan signifikan terhadap loyalitas pelanggan.

Pelanggan yang mendapatkan kepuasan, secara langsung akanmemberikan dampak timbulnya sikap yang loyal terhadap produk yang memberinya kepuasan. Penelitian yang dilakukan oleh Jahanshahi (2011)mengatakan bahwa kepuasan pelanggan berpengaruh terhadap loyalitas pelanggan.Begitu pula dengan penelitian Raharjo(2013)mengatakan bahwa kepuasan berpengaruh positif terhadap loyalitas pelanggan.Sejalan dengan penelitian Lee(2013)yang menunjukkan hasil bahwa kepuasan pelanggan memiliki pengaruh yang positif dan signifikan terhadap loyalitas.

Berdasarkan hasil empiris pada penelitian sebelumnya, hipotesis yang dapat diajukan dalam penelitian ini adalah :

$\mathrm{H}_{3}$ : Kepuasan pelanggan berpengaruh positif dan signifikan terhadap loyalitas pelanggan.

Jika interaksi yang terjadi antara kualitas produk dengan kepuasan pelanggan semakin tinggi maka berdampak bahwa loyalitas pelanggan juga akan semakin tinggi. Maka, peran kepuasan sebagai variabel mediasi dapat memperkuat pengaruh kualitas produk terhadap loyalitas pelanggan.Pernyataan tersebut sesuai dengan penelitian yang dilakukan oleh Asgharian et al., (2012)mengatakan bahwa kualitas produk berpengaruh positif terhadap loyalitas pelanggan dan kepuasan pelanggan sebagai variabel mediasi. Hasil ini sejalan dengan penelitian Alfin(2013)yang menyatakan bahwa ada efek mediasi yang signifikan dari kepuasan pelanggan terhadap kualitas produk dan loyalitas pelanggan artinya kualitas produk secara tidak langsung mempengaruhi loyalitas melalui kepuasan.

Berdasarkan hasil empiris pada penelitian sebelumnya, hipotesis yang dapat diajukan dalam penelitian ini adalah :

$\mathrm{H}_{4}$ : Kepuasan pelanggan secara signifikan memediasi kualitas produk terhadap loyalitas pelanggan.

\section{METODE PENELITIAN}

Penelitian ini dilakukandi Kota Denpasar sebagai ibu kota Provinsi Bali. Alasan peneliti memilih lokasi penelitian KFC di Kota Denpasar karena mobilitas masyarakat Kota Denpasar yang cukup tinggi sehingga KFC banyak digemari karena produknya yang praktis.

Obyek dalam penelitian ini adalah perilaku konsumen khususnya mengenai kepuasan pelanggan terhadap loyalitas pelanggan dalam pembelian KFC yang ditentukan oleh kualitas produk.

Populasi dari penelitian ini adalah pelanggan KFC, dalam hal ini pelanggan yang dituju yaitu individu yang pernah mengkonsumsi dan membeli produk KFC yang berada di wilayah Kota Denpasar, dikarenakan keterbatasan penelitian serta populasi yang tersebar maka jumlah pastinya tidak diketahui. 
Penelitian ini menggunakan 100 responden dari Kota Denpasar. Penelitian dengan menggunakan analisis multivariate dalam melakukan analisis, maka jumlah anggota sampel minimal 5, maksimal $10 \mathrm{kali}$ dari jumlah indikator yang akan diteliti. Jumlah indikator yang digunakan dalam penelitian ini adalah 10 indikator $\mathrm{x} 10=100$ responden. Jadi, responden yang dibutuhkan dalam melakukan penelitian ini adalah sebanyak 100 responden.

Teknik analisis data yang digunakan dalam penelitian ini adalah analisis jalur (path analysis).

Persamaan Sub-struktural 1

$$
\mathrm{M}=\beta_{1} \mathrm{X}+\mathrm{e}_{1}
$$

Persamaan Sub-struktural 2

$$
\mathrm{Y}=\beta_{2} \mathrm{X}+\beta_{3} \mathrm{M}+\mathrm{e}_{2}
$$

\begin{tabular}{|c|c|}
\hline $\mathrm{X}$ & $=$ Kualitas Produk \\
\hline M & $=$ Kepuasan Pelanggan \\
\hline Y & $=$ Loyalitas Pelanggan \\
\hline $\begin{array}{l}\beta_{1}, \beta_{2}, \beta_{3} \\
\mathrm{e}\end{array}$ & $\begin{array}{l}=\text { Koefisien regresi variabel } \\
=\text { Error }\end{array}$ \\
\hline
\end{tabular}

Keterangan :

\section{HASIL DAN PEMBAHASAN}

Uji validitas bertujuan memeriksa apakah kuesioner sebagai instrumen penelitian sudah tepat untuk mengukur apa yang seharusnya diukur. Intrumen dikatakan valid apabila instrumen yang digunakan dapat mengukur apa yang seharusnya diukur. Pengujian validitas dapat dilakukan dengan menghitung korelasi antara skor masing-masing butir pernyataan dengan skor total sehingga didapat Pearson Correlation. Suatu instrumen dikatakan valid jika nilai koefisien korelasi r-hitung lebih besar dari 0,30dengan tingkat kesalahan kurang dari $\alpha=$ 0,05.Hasil uji validitas ditunjukkan pada Tabel 5.

Tabel 5.

Rekapitulasi Hasil Uji Validitas Instrumen Penelitian

\begin{tabular}{ccccc}
\hline Variabel & Indikator & Koefisien Korelasi & Sig. (2-tailed) & Keterangan \\
\hline \multirow{3}{*}{ Kualitas Produk } & $\mathrm{X}_{1}$ & 0,837 & 0,000 & Valid \\
(X) & $\mathrm{X}_{2}$ & 0,813 & 0,000 & Valid \\
& $\mathrm{X}_{3}$ & 0,768 & 0,000 & Valid \\
Kepuasan Pelanggan & $\mathrm{X}_{4}$ & 0,789 & 0,000 & Valid \\
(M) & $\mathrm{M}_{1}$ & 0,893 & 0,000 & Valid \\
& $\mathrm{M}_{2}$ & 0,868 & 0,000 & Valid \\
Loyalitas Pelanggan & $\mathrm{M}_{3}$ & 0,880 & 0,000 & Valid \\
(Y) & $\mathrm{Y}_{1}$ & 0,863 & 0,000 & Valid \\
& $\mathrm{Y}_{2}$ & 0,857 & 0,000 & Valid \\
\hline
\end{tabular}

Sumber:Data diolah, 2019

Hasil uji validitas pada Tabel 5. menunjukkan bahwa seluruh instrumen penelitian yang digunakan untuk mengukur variabel kualitas produk, kepuasan pelanggan, dan loyalitas pelanggan memiliki nilai koefisien korelasi dengan skor total seluruh item pernyataan lebih dari 0,30 . Hal ini menunjukkan bahwa butir- 
butir pernyataan dalam instrumen penelitian tersebut valid dan layak digunakan sebagai instrumen penelitian.

Reliabilitas instrumen menunjukkan derajat ketepatan, ketelitian, atau keakuratan dalam suatu pengukuran instrumen.Uji reliabilitas dilakukan dengan menganalisis pernyataan yang ada dalam instrumen penelitian.Uji reliabilitas terhadap instrumen penelitian ini menggunakan nilai Cronbach's Alpha. Nilai Cronbach'sAlpha dinyatakan reliabel jika nilainya lebih besar atau sama dengan 0,60. Rekapitulasi uji reliabilitas instrumen penelitian dapat dilihat pada Tabel 6 . berikut.

Tabel 6.

Rekapitulasi Hasil Uji Reliabilitas Instrumen Penelitian

\begin{tabular}{cccc}
\hline No. & Variabel & Cronbach's Alpha & Keterangan \\
\hline 1. & Kualitas Produk & 0,808 & Reliabel \\
2. & Kepuasan Pelanggan & 0,854 & Reliabel \\
3. & Loyalitas Pelanggan & 0,849 & Reliabel \\
\hline Sumber: Data diolah, 2019 & &
\end{tabular}

Sumber:Data diolah, 2019

Hasil uji reliabilitas yang disajikan dalam Tabel 6. menunjukkan bahwa seluruh instrumen penelitian memiliki koefisien Cronbach's Alpha lebih dari 0,60. Jadi dapat dinyatakan bahwa seluruh variabel telah memenuhi syarat reliabilitas atau kehandalan sehingga dapat digunakan untuk melakukan penelitian.

Uji normalitas bertujuan untuk mengetahui apakah residual dari model regresi yang dibuat berdistribusi normal atau tidak.Untuk menguji apakah data yang digunakan normal atau tidak, dapat dilakukan dengan menggunakan uji Kolmogorov Smirnov.Apabila koefisien Asymp. Sig. (2-tailed) lebih besar dari 0,05 maka data tersebut dikatakan berdistribusi normal.

Tabel 7.

Hasil Uji Normalitas Struktur 1

\begin{tabular}{lc}
\hline & Unstandardized Residual \\
\hline $\mathrm{N}$ & 100 \\
Asymp. Sig. (2-tailed) Kolmogorov-Smirnov & 0,477 \\
\hline Sumber:Data diolah, 2019 &
\end{tabular}

Tabel 7. menunjukkan bahwa nilai Asymp. Sig. (2-tailed) Kolmogorov Smirnov (K-S) sebesar 0,477. Hasil tersebut mengindikasikan bahwa model persamaan regresi tersebut berdistribusi normal karena nilai Asymp. Sig. (2-tailed) Kolmogorov-Smirnov lebih besar dari nilai 0,05.

Tabel 8.

Hasil Uji Normalitas Struktur 2

\begin{tabular}{lc}
\hline & Unstandardized Residual \\
\hline $\mathrm{N}$ & 100 \\
Asymp. Sig. (2-tailed) Kolmogorov-Smirnov & 0,077 \\
\hline Sumber:Data diolah, 2019 &
\end{tabular}


Tabel 8. menunjukkan bahwa nilai Asymp. Sig. (2-tailed)Kolmogorov Smirnov (K-S) sebesar 0,077.Hasil tersebut mengindikasikan bahwa model persamaan regresi tersebut berdistribusi normal karena nilai Asymp. Sig. (2-tailed)KolmogorovSmirnov lebih besar dari 0,05.

Uji multikolinearitas bertujuan untuk menguji apakah pada model regresi ditemukan adanya korelasi antar variabel. Adanya multikolinearitas dapat dilihat dari nilai tolerance atau variance inflation factor (VIF). Jika nilai tolerance lebih dari $10 \%$ atau VIF kurang dari 10, maka dikatakan tidak ada multikolinearitas.

Tabel 9.

Hasil Uji Multikolinearitas

\begin{tabular}{cccc}
\hline Persamaan Struktur & Variabel & Tolerance & VIF \\
\hline $\mathrm{Y}=\beta_{2} \mathrm{X}+\beta_{3} \mathrm{X}+\mathrm{e} 2$ & Kualitas Produk $(\mathrm{X})$ & 0,512 & 1,953 \\
& Kepuasan Pelanggan $(\mathrm{M})$ & 0,512 & 1,953 \\
\hline
\end{tabular}

Sumber:Data diolah, 2019

Tabel 9. menunjukkan bahwa nilai tolerance dan VIF dari variabel kualitas produk dan kepuasan pelanggan menunjukkan nilai tolerance untuk setiap variabel lebih besar dari 10\% dan nilai VIF lebih kecil dari 10 yang berarti model persamaan regresi bebas dari multikolinearitas.

Uji heteroskedastisitas bertujuan untuk mengetahui apakah dalam model regresi terjadi ketidaksamaan varian dari residual satu pengamatan ke pengamatan yang lain dan pengujian ini dilakukan dengan uji Glejser. Jika nilai signifikansinya diatas 0,05 maka tidak mengandung gejala heteroskedastisitas.

Tabel 10.

Uji Heteroskedastisitas Struktur 1

\begin{tabular}{|c|c|c|c|c|c|c|}
\hline \multirow[b]{3}{*}{ Model } & & \multicolumn{2}{|c|}{ Coefficients $^{\mathrm{a}}$} & \multirow[b]{2}{*}{$\begin{array}{c}\text { Standardized } \\
\text { Coefficients }\end{array}$} & \multirow[b]{3}{*}{$\mathbf{T}$} & \multirow[b]{3}{*}{ Sig. } \\
\hline & & \multicolumn{2}{|c|}{$\begin{array}{c}\text { Unstandardized } \\
\text { Coefficients }\end{array}$} & & & \\
\hline & & B & Std. Error & Beta & & \\
\hline \multirow[t]{2}{*}{ 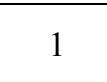 } & (Constant) & ,500 & ,191 & & 2,623 & 010 \\
\hline & Kualitas Produk &,- 038 & 051 &,- 075 &,- 743 & ,459 \\
\hline
\end{tabular}
Sumber: Data diolah, 2019

Tabel 10. menunjukkan bahwa nilai signifikansi dari variabel kualitas produk sebesar 0,459. Nilai tersebut lebih besar dari 0,05 yang berarti tidak terdapat pengaruh antara variabel bebas terhadap absolute residual. Dengan demikian, model yang dibuat tidak mengandung gejala heteroskedastisitas.

Tabel 11. menunjukkan bahwa nilai signifikansi dari variabel kualitas produk dan kepuasan pelanggan masing-masing sebasar 0,945 dan 0,637.Nilai tersebut lebih besar dari 0,05 yang berarti tidak terdapat pengaruh antara variabel bebas terhadap absolute residual. Dengan demikian, model yang dibuat tidak mengandung gejala heteroskedastisitas. 
Tabel 11.

Uji Heteroskedastisitas Struktur 2

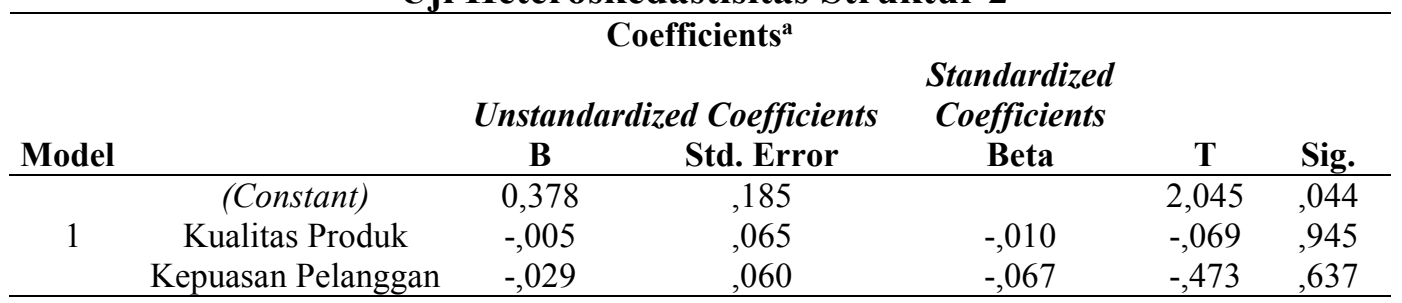

Sumber: Data diolah, 2019

Pengujian data dalam penelitian ini menggunakan teknik analisis jalur (Path Analysis), dimana analisis jalur adalah perluasan dari analisis regresi linier berganda untuk menguji hubungan kausalitas antara 2 atau lebih variabel. Tahapan melakukan analisis jalur yaitu :

Analisis untuk dapat menyusun persamaan struktural yang digunakan, maka terlebih dahulu data yang diperoleh diolah dan dihitung menggunakan program SPSS sehingga diperoleh hasil analisis seperti pada Tabel 12 dan 13.

\section{Tabel 12.}

Hasil Analisis Jalur Persamaan Regresi 1

\begin{tabular}{lccccc}
\hline \multicolumn{1}{c}{ Variabel } & $\begin{array}{c}\text { Unstandardized Coefficients } \\
\text { Std. Error }\end{array}$ & $\begin{array}{c}\text { Standardized } \\
\text { Coefficients } \\
\text { Beta }\end{array}$ & t hitung & $\begin{array}{c}\text { Sig. uji } \\
\text { t }\end{array}$ \\
\hline (Constant) & 0,924 & 0,295 & & 3,134 & 0,002 \\
Kualitas Produk & 0,758 & 0,078 & 0,699 & 9,664 & 0,000 \\
(X) & 0,488 & & & & \\
R Square & 93,387 & & & & \\
F Statistik & 0,000 & & & & \\
Signifikansi Uji & & & & & \\
F & & & & &
\end{tabular}

Sumber:Data diolah, 2019

Berdasarkan hasil analisis jalur substruktur 1 seperti yang disajikan pada Tabel 12. maka dapat diartikan bahwa apabila kualitas produk meningkat maka akan diikuti pula dengan meningkatnya kepuasan pelanggan, maka persamaan strukturalnya sebagai berikut.

$$
\begin{aligned}
& M=\beta_{1} X+\mathrm{e} 1 \\
& M=0,699 X+\mathrm{e} 1
\end{aligned}
$$

Berdasarkan hasil analisis jalur substruktur 2 seperti yang disajikan pada Tabel 13. maka dapat diartikan bahwa apabila kualitas produk dan kepuasan pelanggan meningkat maka akan diikuti pula dengan meningkatnya loyalitas pelanggan, maka persamaan strukturalnya sebagai berikut.

$$
\begin{aligned}
& Y=\beta_{2} X+\beta_{3} M+e_{2} \\
& Y=0,446 X+0,468 M+e_{2}
\end{aligned}
$$


Tabel 13.

Hasil Analisis Jalur Persamaan Regresi 2

\begin{tabular}{|c|c|c|c|c|c|}
\hline \multirow[t]{2}{*}{ Variabel } & \multicolumn{2}{|c|}{ Unstandardized Coefficients } & \multirow{2}{*}{$\begin{array}{c}\text { Standardized } \\
\text { Coefficients } \\
\text { Beta }\end{array}$} & \multirow[t]{2}{*}{ t hitung } & \multirow[t]{2}{*}{$\begin{array}{l}\text { Sig. uji } \\
t\end{array}$} \\
\hline & B & Std. Error & & & \\
\hline (Constant) & $-0,056$ & 0,250 & & $-0,223$ & 0,824 \\
\hline $\begin{array}{l}\text { Kualitas Produk } \\
\text { (X) }\end{array}$ & 0,516 & 0,088 & 0,446 & 5,838 & 0,000 \\
\hline $\begin{array}{l}\text { Kepuasan } \\
\text { Pelanggan(M) }\end{array}$ & 0,500 & 0,081 & 0,468 & 6,132 & 0,000 \\
\hline $\begin{array}{l}R \text { Square } \\
\text { F Statistik }\end{array}$ & $\begin{array}{c}0,710 \\
118,835\end{array}$ & & & & \\
\hline $\begin{array}{l}\text { Signifikansi Uji } \\
\text { F }\end{array}$ & 0,000 & & & & \\
\hline
\end{tabular}

Sumber: Data diolah, 2019

Pengaruh variabel kualitas produk (X) terhadap loyalitas pelanggan (Y) dengan kepuasan pelanggan $(\mathrm{M})$ sebagai variabel mediasi :

$$
\begin{aligned}
\text { indirect effect } & =\beta_{1 \times} \beta_{3} \ldots \ldots \ldots \ldots \ldots \ldots \\
& =0,699 \times 0,468 \\
& =0,327
\end{aligned}
$$

Total pengaruh variabel kualitas produk $(\mathrm{X})$ terhadap loyalitas pelanggan $(\mathrm{Y})$ melalui kepuasan pelanggan $(\mathrm{M})$ sebagai berikut :

$$
\begin{aligned}
\text { total effect } & =\beta_{2}+\left(\beta_{1}\right) \times\left(\beta_{3}\right) \ldots \ldots \ldots \ldots \ldots \ldots \\
& =0,446+(0,699 \times 0,468) \\
& =0,773
\end{aligned}
$$

Berdasarkan model substruktur 1 dan substruktur 2, maka dapat disusun model diagram jalur akhir. Sebelum menyusun model diagram jalur akhir, terlebih dahulu dihitung nilai standar error sebagai berikut :

$$
\begin{aligned}
& \mathrm{Pe}_{\mathrm{i}}=\sqrt{ } 1-\mathrm{Ri}^{2} \ldots \ldots \ldots \ldots \ldots \ldots \ldots \ldots \\
& \mathrm{Pe}_{1}=\sqrt{ } 1-\mathrm{R}_{1}{ }^{2}=\sqrt{ } 1-0,488=0,715 \\
& \mathrm{Pe}_{2}=\sqrt{ } 1-\mathrm{R}_{2}{ }^{2}=\sqrt{ } 1-0,710=0,538
\end{aligned}
$$

Perhitungan pengaruh error $\left(\mathrm{Pe}_{\mathrm{i}}\right)$ mendapatkan hasil pengaruh error $\left(\mathrm{Pe}_{1}\right)$ sebesar 0,715 dan pengaruh error ( $\mathrm{Pe} 2)$ sebesar 0,538. Hasil koefisien determinasi total adalah sebagai berikut:

$$
\begin{aligned}
\mathrm{R}^{2} \mathrm{~m} & =1-\left(\mathrm{Pe}_{1}\right)^{2}\left(\mathrm{Pe}_{2}\right)^{2} \ldots \ldots \\
& =1-(0,715)^{2}(0,538)^{2} \\
& =1-0,511 \times 0,289 \\
& =1-0,148 \\
& =0,852
\end{aligned}
$$

Nilai determinasi total sebesar 0,852 mempunyai arti bahwa sebesar 85,2\% variasi loyalitas pelanggan dipengaruhi oleh variasi kualitas produk dankepuasan pelanggan, sedangkan sisanya sebesar $14,8 \%$ dijelaskan oleh faktor lain yang tidak dimasukkan ke dalam model.

Berdasarkan hasil pengujian pada Tabel 12. dan 13 menghasilkan koefisien $\mathrm{F} \leq 0,05$ dengan koefisien signifikan $\leq 0,05$ hal tersebut menunjukkan kualitas produk dan kepuasan pelanggan berpengaruh secara simultan dan signifikan terhadap loyalitas pelanggan. 
Hasil analisis pengaruh kualitas produk terhadap kepuasan pelanggan diperoleh nilai signifikansi sebesar 0,000 dengan nilai koefisien beta 0,699 . Nilai signifikansi $0,000<0,05$ mengindikasikan bahwa $\mathrm{H}_{0}$ ditolak dan $\mathrm{H}_{1}$ diterima. Hasil ini memiliki arti bahwa kualitas produk berpengaruh positif dan signifikan terhadap kepuasan pelanggan KFC di Kota Denpasar.

Hasil analisis pengaruh kualitas produk terhadap loyalitas pelanggan diperoleh nilai signifikansi sebesar 0,000 dengan nilai koefisien beta 0,446 . Nilai signifikansi $0,000<0,05$ mengindikasikan bahwa $\mathrm{H}_{0}$ ditolak dan $\mathrm{H}_{2}$ diterima. Hasil ini mempunyai arti bahwa kualitas produk berpengaruh positif dan signifikan terhadap loyalitas pelangganKFC di Kota Denpasar.

Hasil analisis pengaruh kepuasan pelanggan terhadap loyalitas pelanggan diperoleh nilai signifikansi sebesar 0,000 dengan nilai koefisien beta 0,468 . Nilai signifikansi $0,000<0,05$ mengindikasikan bahwa $\mathrm{H}_{0}$ ditolak dan $\mathrm{H}_{3}$ diterima. Hasil ini mempunyai arti bahwa kepuasan pelanggan berpengaruh positif dan signifikan terhadap loyalitas pelanggan KFC di Kota Denpasar.

Hasil koefisien jalur pada hipotesis penelitian dapat digambarkan seperti pada Gambar 1. berikut ini :

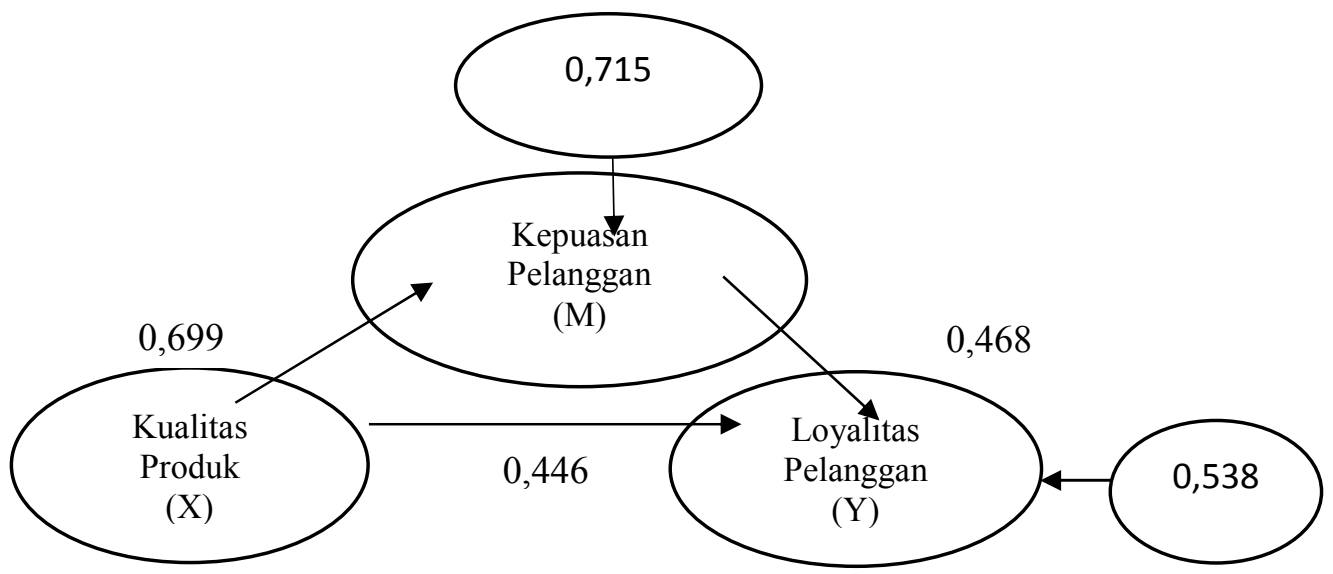

Gambar 1. Validasi Model DiagramJalur Akhir

Sumber:Data diolah, 2019

Gambar 1. merupakan diagram jalur yang mampu menjelaskan besarnya pengaruh langsung dan tidak langsung serta pengaruh total antar variabel. Perhitungan pengaruh antar variabel dirangkum dalam Tabel 14. sebagai berikut:

Tabel 14. menunjukkan bahwa pengaruh langsung kualitas produk (X) terhadap kepuasan pelanggan (M) adalah sebesar 0,699.Pengaruh langsung variabel kulitas produk $(\mathrm{X})$ terhadap loyalitas pelanggan $(\mathrm{Y})$ adalah sebesar 0,446 .Pengaruh langsung variabel kepuasan pelanggan (M) terhadap loyalitas pelanggan(Y) sebesar 0,468. Hal ini menandakan bahwa variabel loyalitas pelanggan lebih besar dipengaruhi oleh kepuasan pelanggan daripada kualitas produk. Adapun pengaruh tidak langsung variabel kulitas produk (X) terhadap loyalitas pelanggan (Y) melalui kepuasan pelanggan (M) adalah sebesar 0,773. Jadi, dapat dijelaskan bahwa lebih besar total pengaruh kualitas produk (X) terhadap loyalitas pelanggan (Y) yang dimediasi melalui kepuasan pelanggan (M), 
daripada pengaruh langsung kualitas produk terhadap loyalitas pelanggan tanpa melalui kepuasan pelanggan.

Tabel 14.

Pengaruh Langsung dan Pengaruh Tidak Langsung serta Pengaruh Total Kualitas Produk (X), Kepuasan Pelanggan (M), dan LoyalitasPelanggan (Y)

\begin{tabular}{cccc}
\hline $\begin{array}{c}\text { Pengaruh } \\
\text { Variabel }\end{array}$ & $\begin{array}{c}\text { Pengaruh } \\
\text { Langsung }\end{array}$ & $\begin{array}{c}\text { Pengaruh Tidak Langsung } \\
\text { melalui Kepuasan Pelanggan (M) } \\
(\mathbf{\beta 1} \mathbf{~} \boldsymbol{\beta 3})\end{array}$ & Pengaruh Total \\
\hline $\mathrm{X} \rightarrow \mathrm{M}$ & 0,699 & & 0,699 \\
$\mathrm{X} \rightarrow \mathrm{Y}$ & 0,446 & 0,327 & 0,773 \\
$\mathrm{M} \rightarrow \mathrm{Y}$ & 0,468 & & 0,468 \\
\hline \multicolumn{2}{l}{ Sumber Data diolah, 2019} & &
\end{tabular}

Uji Sobel merupakan alat analisis untuk menguji signifikansi dari hubungan antara variabel independen dengan variabel dependen yang dimediasi oleh variabel mediator.Uji Sobel dirumuskan dengan persamaan berikut dan dapat dihitung dengan menggunakan Microsoft Excel 2013. Bila nilai kalkulasi Z lebih besar dari 1,96 (dengan tingkat kepercayaan 95\%), maka variabel mediator dinilai secara signifikan memediasi hubungan antara variabel terikat dengan variabel bebas.

Untuk menguji signifikansi pengaruh tidak langsung maka nilai $\mathrm{z}$ dari koefisien ab dihitung dengan rumus sebagai berikut :

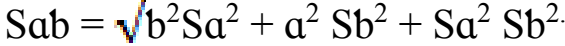

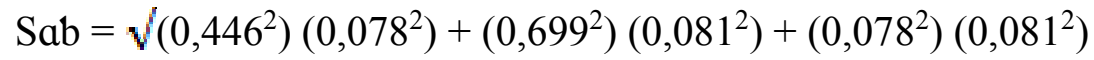

$$
\begin{aligned}
& \mathrm{Sab}=\sqrt{0,004} \\
& \mathrm{Sab}=0,063
\end{aligned}
$$

Keterangan :

$\mathrm{Sab}=$ besarnya standar error tidak langsung

$\mathrm{Sa}=$ standar error koefisien a

$\mathrm{Sb}=$ standar error koefisien $\mathrm{b}$

$\mathrm{a} \quad=$ koefisien jalur $\mathrm{X}$ terhadap $\mathrm{M}$

$\mathrm{b} \quad=$ koefisien jalur $\mathrm{M}$ terhadap $\mathrm{Y}$

Untuk menguji signifikansi pengaruh tidak langsung, maka menghitung nilai $\mathrm{z}$ dari koefisien ab dengan rumus sebagai berikut :

$$
\mathrm{Z}=\frac{a b}{S a b}
$$

$$
Z=\frac{(0,699)(0,468)}{0,063}
$$

$\mathrm{Z}=5,190$

Oleh karena $Z$ hitung sebesar 5,190 > 1,96 artinya kepuasan pelanggan (M) merupakan variabel yang memediasi kualitas produk terhadap loyalitas pelangganKFC di kota Denpasar atau dengan kata lain kualitas produk 
berpengaruh secara tidak langsung terhadap loyalitas pelanggan melalui kepuasan pelanggan.

Hasil pengujian mediasi dengan metode VAF dalam penelitian ini telah memenuhi beberapa persyaratan yaitu pertama, pengaruh langsung ditemukan signifikan saat variabel kepuasan pelanggan (M) belum dimasukkan kedalam model.Kedua, setelah variabel kepuasan pelanggan (M) dimasukkan kedalam model, maka pengaruh tidak langsung ditemukan pula signifikan. Ketiga, melakukan kalkulasi nilai Variance Accounted For (VAF) untuk melihat besarnya variansi pada variabel dependen yang mampu dijelaskan oleh variabel independen melalui variabel mediator. Nilai VAF diperoleh dengan membadingkan besarnya pengaruh tidak langsung terhadap pengaruh total.Besarnya nilai VAF dapat dilihat pada Tabel 15. berikut.

Tabel 15.

Hasil Uji VAF

\begin{tabular}{ccccc}
\hline $\begin{array}{c}\text { Pengaruh } \\
\text { Variabel }\end{array}$ & $\begin{array}{c}\text { Pengaruh Tidak } \\
\text { Langsung }\end{array}$ & $\begin{array}{c}\text { Pengaruh } \\
\text { Total }\end{array}$ & VAF & $\begin{array}{c}\text { Jenis } \\
\text { Mediasi }\end{array}$ \\
\hline $\mathrm{X} \rightarrow \mathrm{Y}$ & 0,327 & 0,773 & $42,3 \%$ & $\begin{array}{c}\text { partial } \\
\text { mediation }\end{array}$ \\
\hline
\end{tabular}

Sumber: Data diolah, 2019

Karena nilai VAF (42,3\%) lebih dari 20 persen, maka dapat dijelaskan bahwa ada efek mediasi. Maka hipotesis yang menyatakan bahwa kepuasan pelanggan berperan dalam memediasi pengaruh kualitas produk terhadap loyalitas pelanggan diterima.

Hasil analisis menunjukkan bahwa kualitas produk berpengaruh positif dan signifikan terhadap kepuasan pelanggan.Hal ini menunjukkan pelanggan KFC merasa puas terhadap kualitas produk yang telah diberikan KFC. Kualitas yang baik merupakan salah satu kunci keberhasilan perusahaan untuk mempertahakan pelanggannya, dimana produk yang baik akan menimbulkan kepuasan bagi pelanggannya.

Dimana hasil penelitian ini sesuai dengan penelitian yang dilakukan Windawati (2008), Chang \& Fong (2010), Sutrisni (2010), Raharjo (2013), Alfin (2013), yang meyatakan bahwa kualitas produk berpengaruh positif dan signifikan terhadap kepuasan pelanggan.

Hasil analisis menunjukkan bahwa kualitas produk berpengaruh positif dan signifikan terhadap loyalitas pelanggan.Hal ini membuktikan bahwa produk berkualitas haruslah sesuai dengan kebutuhan dan keinginan pelanggan. Mempertahankan kualitas produk merupakan suatu hal yang penting bagi perusahaan, karena kualitas yang baik merupakan salah satu kunci keberhasilan perusahaan untuk mempertahankan pelanggannya, dimana produk yang baik akan menimbulkan keputusan membeli dan nantinya berdampak pada peningkatan loyalitas pelanggan.

Hasil ini sesuai dengan penelitian yang dilakukan oleh Foedjiawati \& Samuel (2005), Sutrisni (2010), Chang \& Fong (2010), Alfin (2013), Raharjo (2013) yang menyatakan bahwa kualitas produk berpengaruh positif dan signifikan terhadap loyalitas pelanggan. Hal ini dapat disimpulkan bahwa semakin 
tinggi tingkat kualitas produk maka semakin tinggi pula tingkat loyalitas pelanggan.

Hasil analisis menunjukkan bahwa kepuasan pelanggan berpengaruh positif dan signifikan terhadap loyalitas pelanggan. Loyalitas merupakan sikap setia seseorang atas suatu produk, baik barang maupun jasa tertentu.Loyalitas pelanggan bentuk kelanjutan dari kepuasan pelanggan dalam menggunakan barang atau jasa yang diberikan suatu perusahaan.

Hasil ini sesuai dengan penelitian yang dilakukan yang olehFoedjiawati \& Samuel (2005),Chang\& Fong (2010), Jahanshahi (2011), Asgharian et al.,(2012), Raharjo (2013) yang menyatakan bahwa kepuasan pelanggan berpengaruh positif dan signifikan terhadap loyalitas pelanggan. Penelitian ini dapat menyimpulkan bahwa semakin tinggi tingkat kepuasan pelanggan maka semakin tinggi pula tingkat loyalitas pelanggan.

Hasil analisis menunjukkan bahwa kepuasan pelanggan memediasi pengaruh hubungan kualitas produk terhadap loyalitas pelanggan.Jadi, kepuasan pelanggan berperan sebagai mediator dalam hubungan kualitas produk terhadap loyalitas pelanggan.

Hal ini sesuai dengan penelitian yang dilakukan oleh Barnes (2003), Asgharian et al., (2012), Alfin (2013), Raharjo (2013) ang menyatakan bahwa kepuasan pelanggan memediasi pengaruh kualitas produk terhadap loyalitas pelanggan.

\section{SIMPULAN}

Kualitas produk berpengaruh positif signifikan terhadap kepuasan pelanggan KFC di Kota Denpasar. Ini berarti bahwa semakin tinggi kualitas yang diberikan KFC, maka semakin tinggi pula tingkat kepuasan yang pelanggan rasakan.Kualitas produk berpengaruh positif dan signifikan terhadap loyalitas pelanggan KFC di Kota Denpasar. Ini berarti bahwa semakin tinggi kualitas produk yang diberikan KFC, maka semakin tinggi pula tingkat loyalitas pelanggan terhadap produk KFC.Kepuasan pelanggan berpengaruh positif dan signifikan terhadap loyalitas pelanggan KFC di Kota Denpasar. Ini berarti bahwa semakin tinggi tingkat kepuasan pelanggan terhadap produk KFC, maka semakin tinggi pula tingkat loyalitas pelanggan terhadap produk yang diberikan.Kepuasan pelanggan mampu memediasi pengaruh kualitas produk terhadap loyalitas pelanggan KFC di Kota Denpasar. Peran mediasi kepuasan pelanggan sebagai pemediasi parsial pengaruh kualitas produk terhadap loyalitas pelanggan KFC.

Pihak manajemen KFC agar lebih memperhatikan kualitas produk untuk menjaga loyalitas pelanggan, karena $85 \%$ loyalitas dipengaruhi oleh kualitas produk. Berdasarkan penelitian, pernyataan kualitas produk mengenaimerek fast food KFC yang selalu memberikan kualitas terbaik memiliki nilai rata-rata terendah dibandingkan pernyataan variabel kualitas produk yang lainnya. Untuk mengatasi hal tersebut penting bagi pihak manajemen KFC untuk dapat melakukan inovasi produk yang dapat memikat pelanggan seperti memberikan produk unggulan yang belum dimiliki oleh pesaing dan membuat nama produk yang unik sehingga mudah diingat oleh pelanggan. 
Pihak manajemen KFC agar lebih memperhatikan kepuasan pelanggan untuk menjaga loyalitas pelanggan, karena $85 \%$ loyalitas dipengaruhi oleh kepuasan pelanggan. Berdasarkan penelitian, pernyataan mengenai KFC yang selalu memenuhi keutuhan makanan dibandingkan merek fast foodlain memiliki nilai rata-rata terendah. Untuk mengatasi hal tersebut penting bagi pihak manajemen KFC untuk melakukan survei pada pelanggan agar mengetahui berbagai saran serta usulan-usulan, sehingga pihak manajemen KFC bisa lebih mengembangkan produk yang dimiliki sehingga dapat memenuhi kebutuhan dan keinginan pelanggan tersebut.

Pihak manajemen KFC harus memperhatikan dan mengupayakan loyalitas pelanggan. Berdasarkan penelitian, pernyataan mengenai keinginan pelanggan untuk membeli kembali produk KFC memiliki nilai rata-rata terendah. Untuk mengatasi hal tersebut penting bagi pihak manajemen KFC agar berupaya dalam meningkatkan kualitas yang dimiliki, dikarenakan sudah banyak fast food sejenis yang beredar di masyarakat sehingga diharapkan mampu membuat pelanggan tetap menjatuhkan pilihan pada KFC. Hal-hal yang mungkin bisa dilakukan seperti, menambahkan promo untuk memikat pelanggan agar ingin datang kembali dan membuat KFC food bus di Kota Denpasar untuk menjangkau daerah yang belum terdapat gerai KFC. Segala keterbatasan yang ada dalam penelitian ini agar dapat lebih dikembangkan oleh peneliti selanjutnya, karena masih banyak variabel yang dapat mempengaruhi loyalitas pelanggan misalnya kualitas pelayanan dan harga. Solusi yang dapat dilakukan yaitu melakukan survey pada masyarakat yang lebih luas sehingga hasil yang didapat lebih mewakili kejadian sesungguhnya.

\section{REFERENSI}

Ackaradejruangsri, P. (2013). The Effect of Product Quality Attributes on Thai Consumers ' Buying Decisions. Ritsumeikan Journal of Asia Pasific Studies, 33, 14-23.

Afshar Jahanshahi Scholar in Business Administration. (2011). Study the Effects of Customer Service and Product Quality on Customer Satisfaction and Loyalty. International Journal of Humanities and Social Science, 1(7), 253260. Retrieved from www.ijhssnet.com

Akbar, M. M., \& Parvez, N. (2009). Impact of Service Quality, Trust, And Customer Satifaction On Customer Loyalty. ABAC Journal, 29(1), 24-38.

Alfin, R. (2013). Interdisciplinary Journal of Contemporary Research in Business Mediation Effects on Customer Satisfaction and Service Quality Products Quality of Customer Loyalty. Interdisciplinary Journal of Contemporary Research in Business, 5(6), 735-745.

Amaranggana, A., \& Rahanatha, G. B. (2018). Peran Kepuasan dalam Memediasi Pengaruh Kualitas Produk terhadap Loyalitas Pelanggan. E-Jurnal Manajemen Unud, 7(12), 6872-6900.

Amri, D. (2013). Pengaruh Kepuasan Atas Kualitas Produk Terhadap Loyalitas 
Pengguna Blackberry di Kota Padang. Jurnal Kajian Manajemen Dan Wirausaha, 2(1), 1-11.

Asgharian, R., Salehi, M., Saleki, Z. S., Hojabri, R., \& Nikkheslat, M. (2012). Green Product Quality, Green Customer Satisfaction, and Green Customer Loyalty. International Journal of Research in Management \& Technology, 2(5), 499-503.

Barnes, J. G. (2003). Secrets of Customer Relationship Management (Rahasia Manajemen Hubungan Pelanggan). Yogyakarta: Andi Offset.

Chang, N. J., \& Fong, C. M., Osburg, V. S., Strack, M., Toporowski, W., Roberts, J. a. J. a., Straughan, R. D., \& Roberts, J. a. J. a. (2010). Green product quality, green corporate image, green customer satisfaction, and green customer loyalty. African. Africam Journal of Business Management, 4(13), 2836-2844. https://doi.org/10.1108/07363769910297506

Christian, L. (2013). Citra Merek, Kualitas Produk dan Pengaruhnya terhadap Kepuasan Konsumen pada Makanan Tradisional. Jurnal Riset Ekonomi, Manajemen, Bisnis Dan Akuntansi, 1(3), 284-293.

Damayanti, C., \& Wahyono. (2015). Pengaruh Kualitas Produk, Brand Image Terhadap Loyalitas Dengan Kepuasan Sebagai Variabel Intervening. Management, 4(3), 212-218. https://doi.org/10.1111/1467-6281.00054

Deng, Z., Lu, Y., Wei, K. K., \& Zhang, J. (2010). Understanding Customer Satisfication and Loyalty: An Empirical Study of Mobile Instant Message in China. International Journal of Information Management, 30(4), 289-300.

Farida, N. (2014). Analisis Model Kepuasan terhadap Pembelian Ulang. Jurnal Dinamika Manajemen, 5(2), 200-208.

Foedjiawati, F., \& Samuel, H. (2005). PENGARUH KEPUASAN KONSUMEN TERHADAP KESETIAN MEREK (Studi Kasus Restoran The Prime Steak \&amp; Ribs Surabaya). Jurnal Manajemen Dan Kewirausahaan, 7(1), 7482. https://doi.org/10.9744/jmk.7.1.pp. 74-82

Gaol, A. L., \& Hidayat, K. (2016). Konsumen dan Loyalitas Konsumen. Jurnal Administrasi Bisnis, 38(1), 125-132.

Halim, P., Swasto, B., Hamid, D., \& Firdaus, M. R. (2014). The Influence of Product Quality, Brand Image , and Quality of Service to Customer Trust and Implication on Customer Loyalty ( Survey on Customer Brand Sharp Electronics Product at the South Kalimantan Province ). European Journal of Business and Management, 6(29), 159-166.

Haryanto, R. A. (2013). Strategi Promosi, Kualitas Produk, Kualitas Layanan terhadap Kepuasan Pelanggan pada Restoran McDonald's Manado. Jurnal Riset Ekonomi, Manajemen, Bisnis Dan Akuntansi, 1(4), 1465-1473. 
https://doi.org/10.1016/S0021-9150(98)00283-4

Kotler, P. A. (2012). Principles of Marketing (12th ed.). New Jersey: Prentice Hall.

Kurniawati, D., Suharyono, \& Kusumawati, A. (2014). Merek \& Psikologi Konsumen. Jurnal Administrasi Bisnis, 14(2), 1-9.

Lee, H. S. (2013). Major moderators influencing the relationships of service quality, customer satisfaction and customer loyalty. Asian Social Science, 9(2), 1-11. https://doi.org/10.5539/ass.v9n2p1

Mise, J. K., Nair, C., Odera, O., \& Ogutu, M. (2013). Exploring the determinants of brand loyalty in global FMCG markets of soft drinks consumers in Kenya and India. International Journal of Research in Management Issue, 2(3), 115 Retrieved from http://citeseerx.ist.psu.edu/viewdoc/download?doi=10.1.1.1007.8605\&rep=r ep1\&type $=$ pdf

Mufidah, N. L. (2012). Pola Konsumsi Masyarakat Perkotaan: Studi Deskriptif Pemanfaatan Foodcourt oleh Keluarga. Biokultur, 1(2), 157-178. Retrieved from http://journal.unair.ac.id/filerPDF/05 jurnal nur lailatul----Pola pemanfaatan Foodcourt oleh Keluarga.pdf

Nimas Lailia, Q., Suryoko, S., Saryadi, Chahal, H., Bala, M., Aguilera, D. C., ... Hussein, A. S. (2010). Poster: Forsythiaside inhibits the avian infectious bronchitis virus in cell culture (Proceedings: The Third Academic Conference of Asian Society of Traditional Veterinary Medicine: The 46th Scientific Conference of Japanese Society of Traditional Veterin. International Journal of Marketing Studies, 17(2), 114-126. https://doi.org/10.31937/manajemen.v3i1.172

Pishgar, F., Dezhkam, S., Ghanbarpoor, F., Shabani, N., \& Ashoori, M. (2017). The Impact of Product Innovation on Customer Satisfaction and Customer Loyalty. Kuwait Chapter of Arabian Journal of Business and Management Review, 2(5), 135-142. Retrieved from https://www.scribd.com/document/393361416/Customer-Satisfaction-andCustomer-Loyalty

Pongoh, M. E. (2013). Kualitas Pelayanan, Kualitas Produk Dan Harga Pengaruhnya Terhadap Loyalitas Pelanggan Kartu As Telkomsel Di Kota Manado. Jurnal Riset Ekonomi, Manajemen, Bisnis Dan Akuntansi, 1(4), 86-94. https://doi.org/10.1007/s13398-014-0173-7.2

Pradipta, D. A. A. (2012). Pengaruh Citra Merek (Brand Image) terhadap Loyalitas Konsumen Produk Oli Pelumas PT Pertamina (PERSERO) Enduro $4 T$ di Makassar. Skripsi. Sarjana Jurusan Akuntansi Fakultas Ekonomi dan Bisnis Universitas Hasanuddin. Retrieved from https://media.neliti.com/media/publications/189618-ID-pengaruh-citra- 
merek-terhadap-faktor-psi.pdf

Prasastono, N., \& Pradapa, S. Y. F. (2012). Kualitas Produk dan Kualitas Pelayanan Terhadap Kepuasan Konsumen Kentucky Fried Checken Semarang Candi. Dinamika Kepariwisataan, 11(2), 13-23.

Raharjo, A. (2013). Pengaruh Kualitas Produk terhadap Loyalitas Konsumen yang Dimediasi oleh Kepuasan Konsumen Pengguna Kartu "AS." Jurnal Manajemen Dan Bisnis, 922-925. https://doi.org/10.4135/9781412963947.n337

Román, S. (2010). Relational consequences of perceived deception in online shopping: The moderating roles of type of product, consumer's attitude toward the internet and consumer's demographics. Journal of Business Ethics, 95(3), 373-391. https://doi.org/10.1007/s10551-010-0365-9

Ruggieri, A., \& Silvestri, C. (2014). Quality and Custimer Satisfication: Relationship and Customer Behaviour. A Case Study. International Journal of Managerial Studies and Research, 2(10), 22-35. Retrieved from http://www.ncbi.nlm.nih.gov/pubmed/8136739

Sembiring, I. J., Suharyono, \& Kusumawati, A. (2014). Pengaruh Kualitas Produk dan Kualitas Pelayanan terhadap Kepuasan Pelanggan dalam Membentuk Loyalitas Pelanggan (Studi pada Pelanggan McDonald's MT. Haryono Malang). Jurnal Administrasi Bisnis, 15(1), 1-10. https://doi.org/10.1080/00423114.2017.1410184

Shahin, A., Abandi, A. A., \& Javadi, M. H. M. (2011). Analyzing The Relationship Between Customer Satisfaction and Loyalty in The Software Industry. International Journal of Business and Social Science, 2(23), 129136.

Sutrisni. (2010). Analisis Pengaruh Kualitas Produk, Kualitas Pelayanan, Desain Produk, Harga Dan Kepercayaan Terhadap Loyalitas Pelanggan Indosat Im3 Pada Mahasiswa Fakultas Ekonomi Universitas Diponegoro Semarang. Skripsi. Sarjana Jurusan Manajemen Fakultas Ekonomi Universitas Diponegoro Semarang. Retrieved from http://eprints.undip.ac.id/23344/1/SKRIPSI_LENGKAP.pdf

Suwarni, \& Mayasari, S. D. (2011). Pengaruh Kualitas Produk dan Harga terhadap Loyalitas melalui Kepuasan Konsumen. Jurnal Ekonomi Dan Bisnis, (1), 76-84.

Thakur, S., \& Singh. (2011). Impact of Service Quality, Customer Satisfication and Trust on Customer Loyalty: A Study With Special Reference to Telecommunication Company in Madhya Pradesh (India). International Journal of Business Economic \& Management Research, 1(2), 78-99.

Tjiptono, F., \& Gregorius, C. (2015). Service Quality \& Satisfication (3rd ed.). 
E-Jurnal Manajemen, Vol. 8, No. 12, 2019 : 7349-7369

Yogyakarta: Andi Offset.

Wahjono. (2010). Manajemen Pemasaran Bank (1st ed.). Yogyakarta: Graha Ilmu.

Wiguno, S. H. (2014). Analisis Pengaruh Kualitas Layanan terhadap Kepuasan Konsumen Mini Market (Studi Kasus Pada Konsumen Indomaret Di Mojosongo Surakarta). Skripsi. Sarjana Jurusan Manajemen Fakultas Ekonomi dan Bisnis Universitas Muhammadiyah Surakarta.

Windawati, R. E. (2008). Hubungan Antara Persepsi terhadap Kuaitas Produk dengan Loyalitas Pelanggan pada PT. Natasha Skin Care Yogyakarta. 